\title{
Ganoderma diversity from smallholder oil palm plantations in peatlands of Kampar District, Indonesia based on mycelia morphology and somatic incompatibility
}

\author{
ANTHONY HAMZAH, RACHMAD SAPUTRA", FIFI PUSPITA, BESRI NASRUL, IRFANDRI, \\ NOVITA SARI DEPARI \\ Department of Agrotechnology, Faculty of Agriculture, Universitas Riau. J1. H.R. Soebrantas Km. 12.5, Panam, Pekanbaru 28293, Riau, Indonesia \\ Tel./fax.: +62-761-63271, ^email: rachmadsaputra@lecturer.unri.ac.id
}

Manuscript received: 4 November 2020. Revision accepted: 7 December 2020.

\begin{abstract}
Hamzah A, Saputra R, Puspita F, Nasrul B, Irfandri, Depari NS. 2021. Ganoderma diversity from smallholder oil palm plantations in peatlands of Kampar District, Indonesia, based on mycelia morphology and somatic incompatibility. Biodiversitas 22: 16-22. Basal Stem Rot disease is caused by the pathogenic fungus Ganoderma boninense which has caused major economic losses in the palm oil industry. Ganoderma boninense has been reported not only infecting crops in the field, but also attacking at the immature phase of the plant even in the nursery. Studies related to Ganoderma diversity in oil palm plantations in Riau, Indonesia have not been widely reported. Ganoderma genetic diversity is important because its provide information regarding the mechanism of infection and the spatial distribution. The Ganoderma spp. isolates were collected from three blocks of smallholder oil palm plantation in Deli Makmur Village, Kampar District, Riau Province, Indonesia and brought to Plant Disease Laboratory, Faculty of Agriculture, Riau University, Pekanbaru, Indonesia. This experimental research was conducted using six Ganoderma isolates (Gan1, Gan2, Gan3, Gan4, Gan5, and Gan6) on the parameters of colony diameter and growth speed, while for the parameters of the morphological diversity of Ganoderma mycelium and the diversity based on somatic incompatibility assay was carried out descriptively. The results of this study show that oil palm plants in smallholder plantations in Kampar District are infected by two groups of Ganoderma based on morphology characteristics using UPGMA dendrogram, but different among isolates based on genetically using somatic incompatibility assay. For the next confirmation, it is necessary to further identify whether the six isolates are different species using molecular identification.
\end{abstract}

Keywords: Basidioma, diversity, Ganoderma, somatic incompatibility

\section{INTRODUCTION}

Riau Province has the largest oil palm plantation area in Indonesia. Based on data from the Central Bureau of Statistics (2019), the area of oil palm plantations in Riau has reached $2,850,003$ ha of the total land area, namely $14,996,010$ ha or $19 \%$ of the total national area, where $39 \%$ of the total area of oil palm plantations is found on peatland. However, in its development, oil palm plantations are still faced with one major obstacle, namely the incidence of stem rot disease which causes losses due to plant mortality. Basal Stem Rot (BSR) disease is a major disease that is still difficult to control in oil palm plantations, especially in Indonesia. This disease is caused by the pathogenic fungus Ganoderma spp. which has caused major economic losses in the palm oil industry, because it can cause death by up to $50 \%$ resulting in a decrease in oil palm production (Darmono 1998).

Ganoderma spp. has been reported not only infecting crops in the field, but also attacking at the immature phase of the plant even in the nursery. In Indonesia, several oil palm plantations reported plant mortality which reached more than 35\% in Tanjung Selamat (Susanto et al. 2008). In Malaysia, Idris et al. (2003) reported that plant mortality can reach more than $80 \%$ of oil palm trees that have half their economic life span. This pathogen is known to not only cause stem rot, Susanto et al. (2013) have reported that in Labuhan Batu, North Sumatra, Ganoderma can also cause Upper Stem Rot (USR) symptoms which are predominantly found on peatlands, and Rakib et al. (2014a) also reported the occurrence of upper stem rot disease in Sarawak, Malaysia.

To date, there are 15 species of Ganoderma spp. causes of Basal Stem Rot disease have been reported, including $G$. boninense (Cooper et al. 2011), G. chalceum, $G$. miniactocinctum, G. tornatum, and G. zonatum (Elliott and Broschat 2001). G. boninense is more virulent than other species as a cause of BPB in some cases. In South Africa, root rot is caused by G. lucidum Karst. while in Nigeria it was caused by G. zonatum, G. encidum, G. colossus, and G. applanatum. In Malaysia, the species identified as causing stem rot is $G$. boninense Pat., while G. tornatum is only found growing in the highlands with high rainfall. In Indonesia, the $G$. boninense Pat. identified as the most common fungal species attacking oil palm (Jing 2007).

Ganoderma spp. is a soil-borne pathogen, with three ways of spreading, namely contact of plant roots with Ganoderma spp. inoculum sources, through the air with basidiospore, and through secondary inoculums in the form of oil palm stumps as alternative hosts (Susanto et al. 2013). Pinaria and Assa (2017), explain that the pathogens can be spread horizontally in the soil up to about 2 meters 
from the infected source to the healthy plants root. To date, more than 250 species from the genus Ganoderma spp. around the world. This fungus has a porous basidioma at the bottom. The basidioma varies widely in size, shape, and color. The size of the fruit body can reach a diameter of 15 $\mathrm{cm}$ and a thickness of $5 \mathrm{~cm}$, the color of the fruit body ranges from light brown to dark brown and some even orange. The upper part of the basidioma is slightly shiny with a white underside (Henessy and Daly 2007).

Ganoderma spp. can be identified by observing the character macroscopic of basidioma and the colony on medium, and also microscopic by the mycelia. The fruiting body of Ganoderma spp. macroscopically appears as a small white bulb at first and develops into a fan-like, thick and hard shape. The color of the upper surface of the basidioma varies from light brown to dark brown, usually looks shiny, especially when it is young. The outer surface is white, the lower surface is dull white, when touched it will immediately turn bluish-gray and the lower layer of the fruiting body consists of a layer of pores, where basidium and basidiospores are formed (Peterson 2006). Studies related to Ganoderma diversity in oil palm plantations in Riau have not been widely reported. Purnamasari et al. (2012) have carried out Ganoderma isolation and molecular identification from infected palm oil in Padang and Pontianak. Ganoderma genetic diversity is important to know because each has specifications in causing disease in plants. Lack of information on the diversity of Ganoderma species causes inaccurate in determining control measures. This genetic diversity will also provide information regarding the mechanism of infection and spread in the land, so this study is necessary.

\section{MATERIALS AND METHODS}

\section{Study area}

This research was conducted from August to November 2020. The Ganoderma basidioma was collected from the smallholder oil palm plantations in Deli Makmur Village, Kampar Timur Subdistrict, Kampar District, Riau Province, Indonesia. The sample was taken from infected oil palm tree on the three blocks of oil palm plantations (Figure 1), The first block is located on the site $0^{\circ} 30^{\prime} 18^{\prime \prime} \mathrm{N}$ $101^{\circ} 11^{\prime} 09 " \mathrm{E}$, the second block is located on the site $0^{\circ} 30^{\prime} 16^{\prime \prime} \mathrm{N}-101^{\circ} 11^{\prime} 05^{\prime \prime} \mathrm{E}$ and the third block is located on the site $0^{\circ} 30^{\prime} 23^{\prime \prime} \mathrm{N}-101^{\circ} 11^{\prime} 04^{\prime \prime} \mathrm{E}$. The basidioma samples were brought to Plant Disease Laboratory, Faculty of Agriculture, Riau University, Pekanbaru, Indonesia for further assessment.

\section{Procedures \\ Sample collection and isolation}

Ganoderma spp. collected from infected plants of smallholder oil palm plantations in the peatlands of the Kampar District. The field samples were isolated from the basidioma using Potato Dextrose Agar (PDA). The basidioma was cut to a size of about $1 \mathrm{~cm} \times 1 \mathrm{~cm}$, then the fruit body is soaked in $70 \%$ alcohol for 1 minute. The pieces of the fruit body are transferred to $0.5 \% \mathrm{NaOCl}$ solution for 1 minute then rinsed using sterile water 3 times and dry. The basidioma was placed in PDA medium and then incubated at $28^{\circ} \mathrm{C}$. A total of six isolates of Ganoderma sp. namely: Gan1, Gan2, Gan3, Gan4, Gan5, and Gan6 were purified.

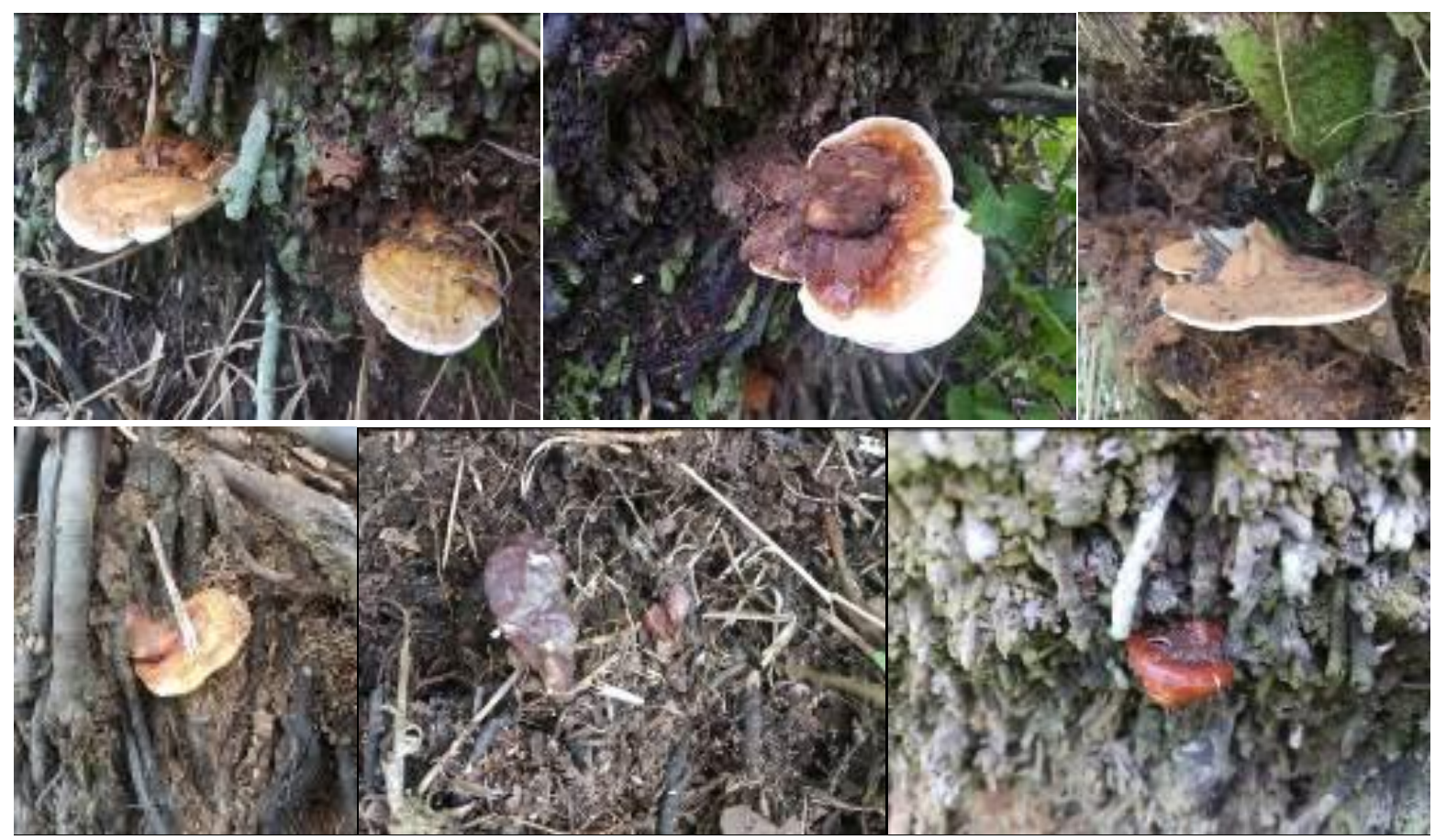

Figure 1. The diversity of Ganoderma spp. basidioma from infected oil palm tree in Deli Makmur Village, Kampar District, Riau, Indonesia 
Table 1. Morphological characterization to describe the similarity coefficient of Ganoderma isolates

\begin{tabular}{|c|c|c|c|}
\hline Character & Description & Character & Description \\
\hline \multirow[t]{3}{*}{ Mycelia density } & Thin & Mycelia texture & Smooth \\
\hline & Dense & & Rough \\
\hline & Dense at center only & & Fluffy \\
\hline \multirow[t]{3}{*}{ Surface texture } & Adpressed & Colony concentric ring & Absence \\
\hline & Moderately wavy & & Presence \\
\hline & Strongly wavy & & \\
\hline \multirow[t]{5}{*}{ Surface pigmentation } & No pigmentation (White) & Reverse pigmentation & No pigmentation (white) \\
\hline & Pale yellow & & Pale yellow \\
\hline & Yellow & & Yellow \\
\hline & Yellowish-brown & & Brownish-yellow \\
\hline & Dark yellowish brown & & Yellowish-brown \\
\hline
\end{tabular}

\section{Morphological diversity of Ganoderma spp. mycelium}

Ganoderma morphological diversity was carried out by observing the mycelium growing on PDA media. The observations carried out included: days for full plate, mycelia density, mycelia texture, surface texture, colony concentric ring, surface and reverse pigmentation color. That characteristic then used as quantitative data adopted from Rakib et al. (2014b) and describe in Table 1. The similarity coefficient was shown on dendrogram using unweighted pair group method of arithmetic averages (UPGMA) (Pilotti et al. 2004).

\section{Diameter and growth speed of Ganoderma sp. isolates}

Observation of Ganoderma spp. growth was done by measuring the colony diameter and growth rate of fungal isolates grown on PDA medium. The colony diameter of Ganoderma spp. measured daily until the mycelial growth of one of any isolate filled the petri dish. The average growth speed was calculated. Growth speed (V) calculation of Ganoderma spp. carried out based on the formula V = D $(n+1)-D n$, based on the diameter (D) of the colony form 1 day up to 7 days after inoculation (n).

Ganoderma spp. diversity based on somatic incompatibility assay

The somatic incompatibility test was carried out using the method of Latifah and Ho (2005) by pairing two different Ganoderma fungi isolates on PDA media in a petri dish $(9 \mathrm{~cm}$ in diameter). The inoculum block was taken from the initial plate with a size of $\pm 3 \mathrm{~mm}^{2}$, placed with a distance of $\pm 2 \mathrm{~mm}$ between the two isolates. The tissue cultures were incubated at $25^{\circ} \mathrm{C}$ in the incubation room. The results of the somatic incompatibility test were evaluated after 5 days of planting by assessing the incompatibility reactions between isolates. Compatible isolates merged into single colony (self-pairing), whereas incompatible isolates formed inhibition zone or barrage.

\section{Data analysis}

The diameter and growth speed of Ganoderma sp. isolates data obtained were analyzed statistically by ANOVA using SPSS then followed by Duncan New Multiple Range Test (DNMRT) at the 5\% level by using SAS 9.4. The morphological diversity data of Ganoderma spp. mycelium and somatic incompatibility assay were analyzed descriptively and the data presented on tables and figures. The similarity coefficient dendrogram then analyzed using UPGMA with Numerical Taxonomy System (NTSYS-pc) program.

\section{RESULTS AND DISCUSSION}

\section{Morphological diversity of Ganoderma spp mycelium}

The data in Table 2 shows the diversity of Ganoderma spp. based on the morphology of mycelium that grows on PDA medium. The Gan6 isolate was the one that filled the petri dish the fastest with 6 days after inoculation. Meanwhile, Gan 2 and Gan3 isolates took care of the Petri dishes for 7 days after inoculation, while other isolates took more than 7 days after inoculation. Mycelium morphology, of the 6 isolates that were observed showed a variety of mycelia density and mycelia structure (Figure 2). However, the surface texture was only Gan 3 which showed strongly wavy, and Gan 5 which did not show any concentric colony rings. Two Ganoderma isolates showed yellowish-brown to brownish-yellow and others have shown no surface pigmentation (white) color, and only Gan3 and Gan4 showed a brownish yellow color on the reverse pigmentation color

Figure 3 shows the dendrogram of the similarity in morphological characteristics of 6 Ganoderma isolates obtained and there are 2 major groups where a cutoff value of 0.70. In Group 1 there were 2 isolates that had a similar morphological similarity with a $90 \%$ similarity coefficient, namely the Gan1 and Gan2 isolates, while the Gan4 isolates were separated with a similarity coefficient of only about $76 \%$. Group 2 are the Gan 2 and Gan 5 isolates which have a similarity coefficient of about $80 \%$, and the Gan3 isolates are separated from the two isolates with a similarity coefficient of only $72 \%$.

\section{Colony diameter and growth speed of Ganoderma sp. isolates}

Table 3 showed that the Ganoderma sp. isolate Gan6 showed the highest growth rate compared to other isolates, so that this isolate was able to produce a colony diameter of $9 \mathrm{~cm}$ at 6 days after inoculation. Figure 4 shows a graph of the development and growth of Ganoderma sp. isolates of Gan6 were increasing, while isolates of Gan2 and Gan3 showed moderate growth rates, and isolates of Gan1, Gan4, Gan5 showed slower growth rate which meant slower colony development than other isolates. 

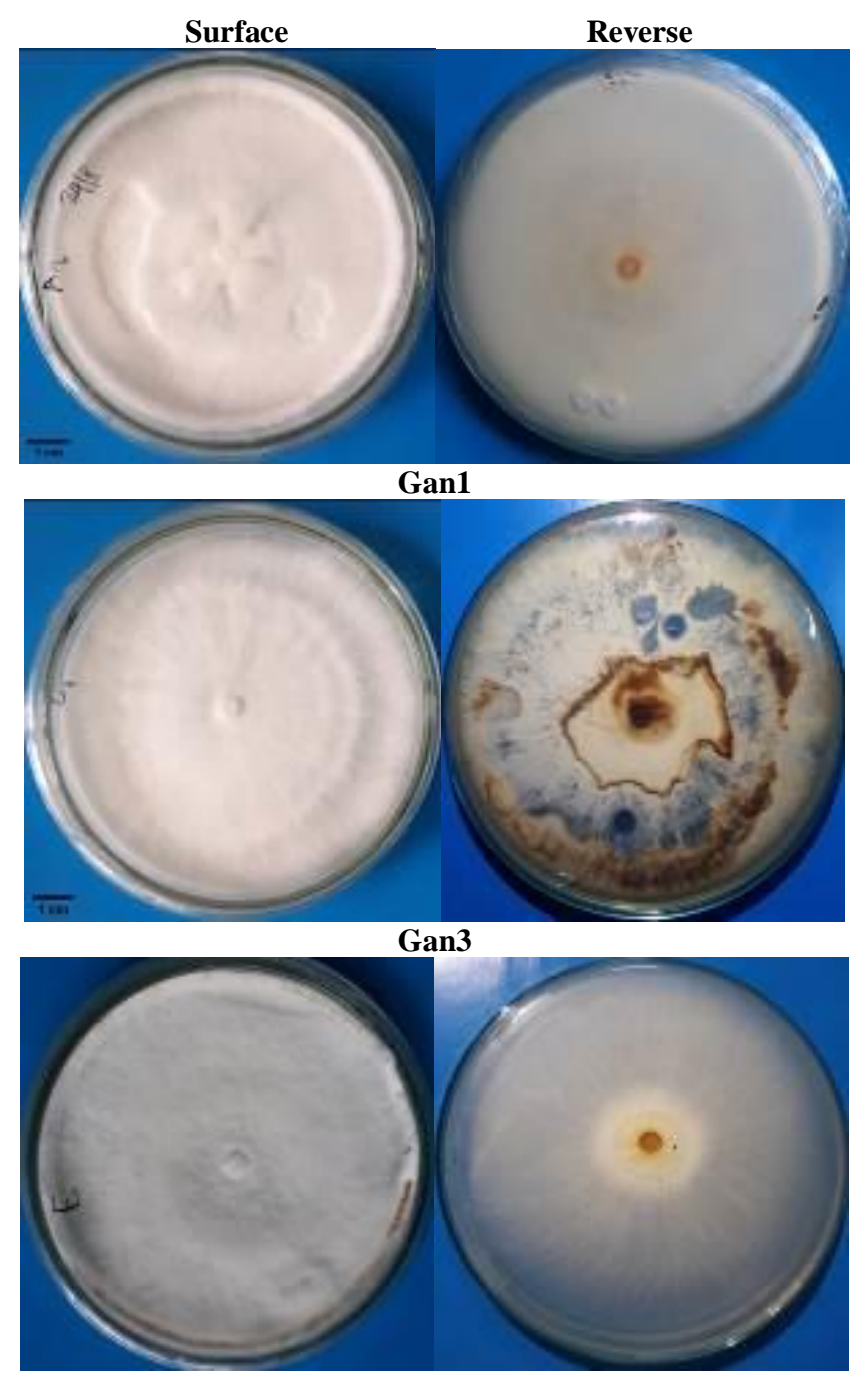

Gan5

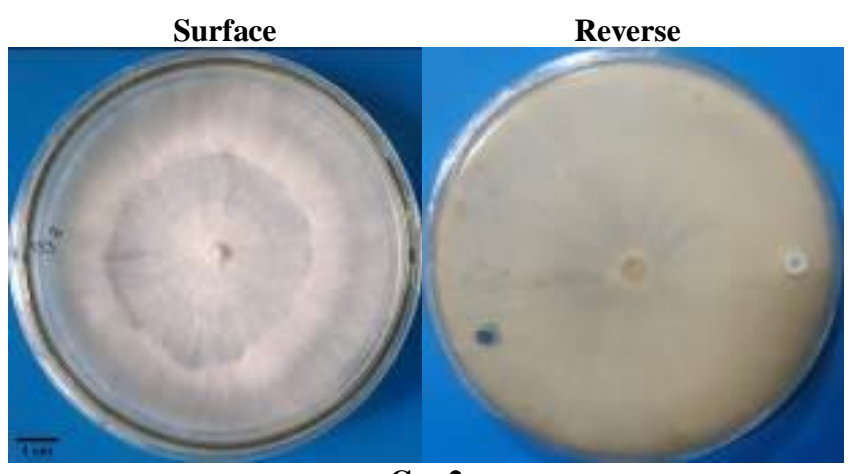

Gan2

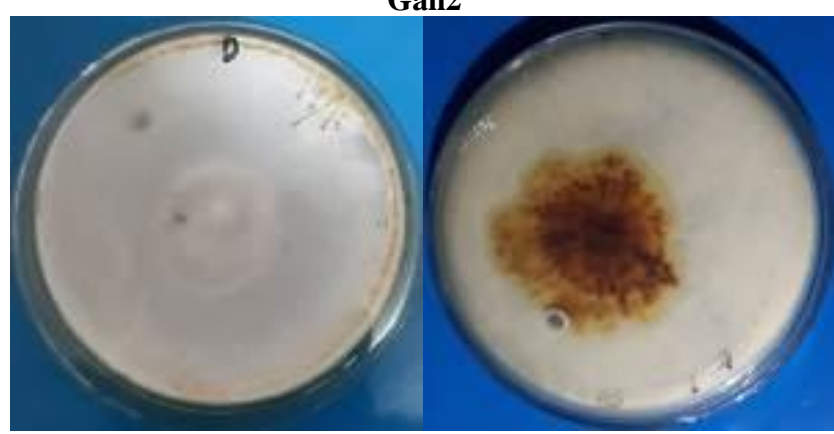

Gan4

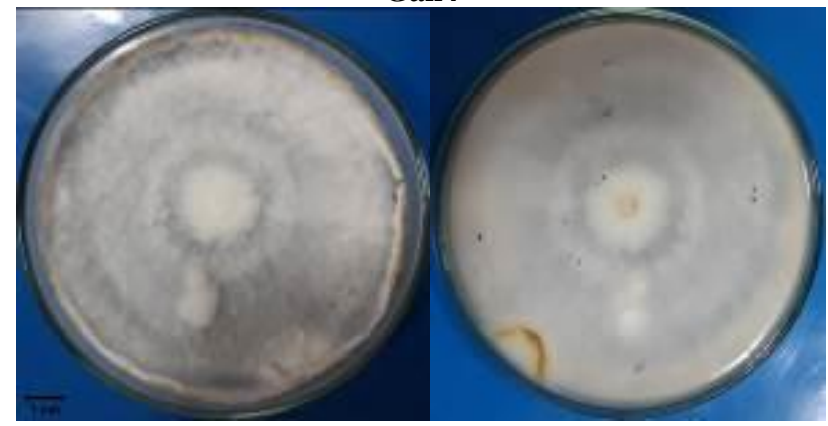

Gan6

Figure 2. Morphological characteristic of six Ganoderma spp. isolates on PDA medium

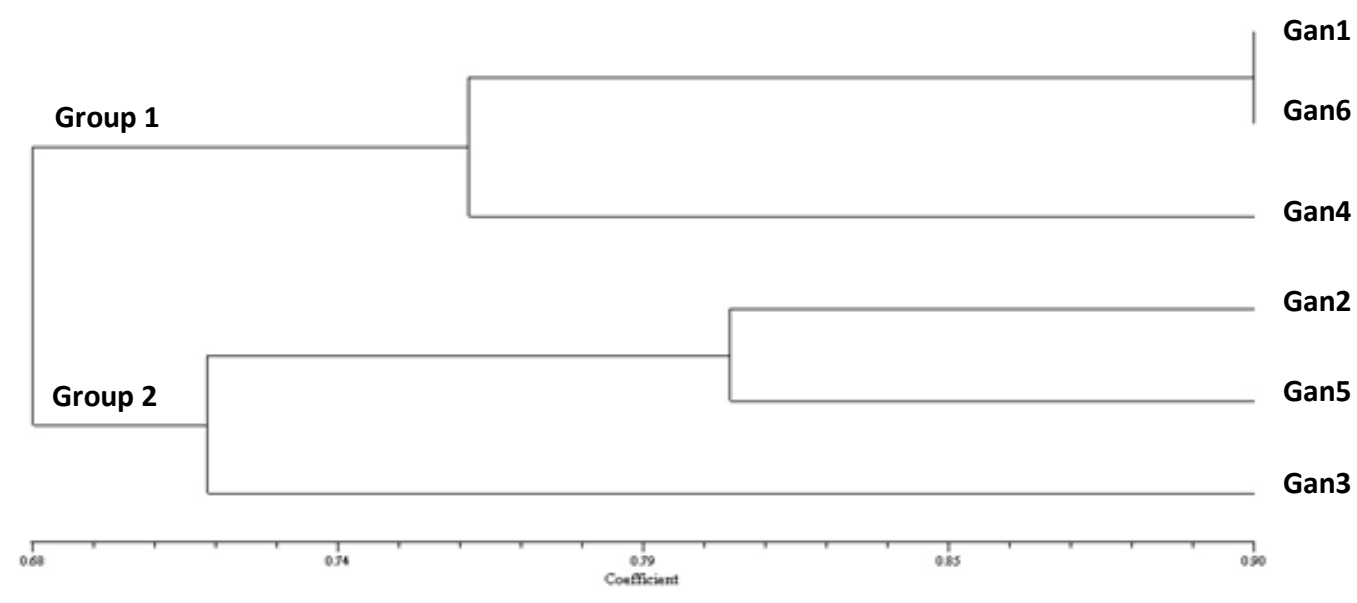

Figure 3. Dendrogram (UPGMA) based on morphological characteristics generated using 6 Ganoderma spp. isolate mycelia 
Table 2. Morphological diversity of Ganoderma spp. mycelia on PDA medium

\begin{tabular}{lcllllll}
\hline $\begin{array}{c}\text { Ganoderma } \\
\text { sp. isolates }\end{array}$ & $\begin{array}{c}\text { Days for } \\
\text { full plate }\end{array}$ & Mycelia density & $\begin{array}{c}\text { Mycelia } \\
\text { texture }\end{array}$ & Surface texture & $\begin{array}{c}\text { Colony } \\
\text { concentric ring }\end{array}$ & $\begin{array}{c}\text { Surface } \\
\text { pigmentation color }\end{array}$ & $\begin{array}{c}\text { Reverse } \\
\text { pigmentation color }\end{array}$ \\
\hline Gan1 & $>7$ & Dense & Smooth & Moderately wavy & Presence & White & White \\
Gan2 & 7 & Dense & Fluffy & Moderately wavy & Presence & Yellowish-brown & White \\
Gan3 & 7 & Dense & Fluffy & Strongly wavy & Presence & White & Brownish-yellow \\
Gan4 & $>7$ & Dense at center only & Smooth & Moderately wavy & Presence & Dark yellowish brown Brownish-yellow \\
Gan5 & $>7$ & Dense & Fluffy & Moderately wavy & Absence & White & White \\
Gan6 & 6 & Dense at center only & Smooth & Moderately wavy & Presence & White & White \\
\hline
\end{tabular}

\section{Ganoderma spp diversity based on somatic incompatibility assay}

Based on somatic incompatibility assay, all six isolates except self-pairing isolates showed incompatibility reaction. The pairing reaction of two different Ganoderma sp. isolates showed in Table 4. This data shows that the six isolates are genetically different from each other although they are morphologically similar based on colony diameter and growth speed on PDA medium. Data in Table 4 showed there are two forms of somatic incompatibility result in several Ganoderma sp. isolates, namely barrage and inhibition zones. Some pairing result shows the pigmentation on the barrage (Table 5 and Figure 5). This somatic incompatibility assay result showed that the smallholder oil palm plantations in Deli Makmur Village, Kampar District were infected by several different Ganoderma species.

\section{Discussion}

The use of basidioma morphological information in determining Ganoderma diversity is considered insufficient. Seo and Kirk (2000) stated that the identification process is not sufficient based solely on differences in the shape of the basidioma, because some basidioma has a similar shape, therefore it is necessary to pay attention to other criteria, namely spore, and mycelia morphology characteristics. The observations results of the morphological characteristics on the mycelia showed similar characteristics to the study conducted by Rakib et al. (2014b) who showed the species $G$. boninense and $G$. zonatum that confirm by molecular identification.

Ganoderma sp. mycelial growth rate of Gan6 isolate on PDA medium provides information regarding the ability of Ganoderma to develop. This rapid growth of fungal mycelia causes disease covering plant parts quickly. The presence of fungal mycelium in the plant transport tissue causes the inhibition of water transportation, and nutrients needed by plants, as a result, the initial symptoms appear in the form of chlorosis on the leaves followed by necrosis (Riantin 2009). The growth rate will be in line with the colony's wide diameter which will affect the ability of microbes to fill space and absorb nutrients (Saputra et al. 2019; Elfina et al. 2016).
Table 3. Growth speed and colony diameter of Ganoderma sp. isolates at several days after inoculation on PDA medium

\begin{tabular}{ccc}
\hline $\begin{array}{c}\text { Ganoderma } \text { sp. } \\
\text { isolates }\end{array}$ & $\begin{array}{c}\text { Growth speed of } \\
\text { Ganoderma spp. } \\
\left(\text { cm.day }^{-1}\right)\end{array}$ & $\begin{array}{c}\text { Colony } \\
\text { diameter on 6 } \\
\text { days }(\mathbf{c m})\end{array}$ \\
\hline Gan1 & $1.07 \pm 0.15 \mathrm{~b}$ & $6.43 \pm 0.93 \mathrm{~b}$ \\
Gan2 & $1.43 \pm 0.08 \mathrm{a}$ & $8.55 \pm 0.45 \mathrm{a}$ \\
Gan3 & $1.38 \pm 0.03 \mathrm{a}$ & $8.30 \pm 0.20 \mathrm{a}$ \\
Gan4 & $0.96 \pm 0.09 \mathrm{~b}$ & $5.75 \pm 0.55 \mathrm{~b}$ \\
Gan5 & $0.85 \pm 0.01 \mathrm{~b}$ & $5.08 \pm 0.03 \mathrm{~b}$ \\
Gan6 & $1.50 \pm 0.00 \mathrm{a}$ & $9.00 \pm 0.00 \mathrm{a}$ \\
\hline
\end{tabular}

Note: In a column, the numbers followed by unequal lowercase letters are significantly different according to the DNMRT test at the $5 \%$ level of probability

Table 4. Somatic incompatibility result of Ganoderma spp. on PDA medium

\begin{tabular}{ccccccc}
\hline $\begin{array}{c}\text { Ganoderma } \\
\text { sp. isolate }\end{array}$ & Gan1 & Gan2 & Gan3 & Gan4 & Gan5 & Gan6 \\
\hline Gan1 & $\sqrt{ }$ & $\mathrm{x}$ & $\mathrm{x}$ & $\mathrm{x}$ & $\mathrm{x}$ & $\mathrm{x}$ \\
Gan2 & $\mathrm{x}$ & $\sqrt{ }$ & $\mathrm{x}$ & $\mathrm{x}$ & $\mathrm{x}$ & $\mathrm{x}$ \\
Gan3 & $\mathrm{x}$ & $\mathrm{x}$ & $\sqrt{ }$ & $\mathrm{x}$ & $\mathrm{x}$ & $\mathrm{x}$ \\
Gan4 & $\mathrm{x}$ & $\mathrm{x}$ & $\mathrm{x}$ & $\sqrt{ }$ & $\mathrm{x}$ & $\mathrm{x}$ \\
Gan5 & $\mathrm{x}$ & $\mathrm{x}$ & $\mathrm{x}$ & $\mathrm{x}$ & $\sqrt{ }$ & $\mathrm{x}$ \\
Gan6 & $\mathrm{x}$ & $\mathrm{x}$ & $\mathrm{x}$ & $\mathrm{x}$ & $\mathrm{x}$ & $\sqrt{ }$ \\
\hline
\end{tabular}

Note: $\sqrt{ }=$ self-pairing, $x=$ incompatible

Table 5. Somatic incompatibility form of Ganoderma spp. isolates on PDA medium

\begin{tabular}{ccc}
\hline $\begin{array}{c}\text { Ganoderma spp. } \\
\text { isolates }\end{array}$ & $\begin{array}{c}\text { Somatic } \\
\text { incompatibility form }\end{array}$ & $\begin{array}{c}\text { Pigmentation } \\
\text { form }\end{array}$ \\
\hline Gan1 x Gan2 & Barrage & Absence \\
Gan1 x Gan3 & Barrage & Presence \\
Gan1 x Gan4 & Barrage & Absence \\
Gan1 x Gan5 & Barrage & Presence \\
Gan1 x Gan6 & Barrage & Absence \\
Gan2 x Gan3 & Barrage & Absence \\
Gan2 x Gan6 & Barrage & Absence \\
Gan3 x Gan6 & Barrage & Absence \\
Gan4 x Gan5 & Barrage & Absence \\
Gan4 x Gan6 & Barrage & Absence \\
Gan5 x Gan6 & Barrage & Absence \\
Gan2 vs Gan4 & Inhibition zone & Absence \\
Gan2 vs Gan5 & Inhibition zone & Presence \\
Gan3 vs Gan4 & Inhibition zone & Presence \\
Gan3 vs Gan5 & Inhibition zone & Presence \\
\hline
\end{tabular}


Another method in determining the genetic diversity of Ganoderma that can be used is somatic incompatibility. Hidayati and Nurrohmah (2015) stated that somatic incompatibility in basidiomycetes is the rejection of genetically different mycelia which functions to keep genetic changes in an individual. Somatic incompatibility regulates the rejection and recognition of alleles or corresponding and incompatible genes that follow the formation of cells body in a group of organisms. The study of somatic incompatibility can be used to determine the distribution of genotypes in a population, besides that, it can also be used to determine whether each tree affected by the fungus comes from the same or different fungal clones which can later be used to analyze the population and distribution of fungi in the field (Puspitasari and Rimbawanto 2010; Fries 1987). Rakib et al. (2014b) tested 46 Ganoderma samples, where somatic incompatibility formed from all tested isolates that showed a genetic difference from one another even in isolates from the same species.

Latiffah and Ho (2005) also stated that these genetic variations occur in pathogens originating from the same or close to species. Incompatibility reactions can be shown in various forms of demarcation, namely the phenomenon of inhibition zone formation between paired mycelium, the formation of dam zones and formation of demarcation lines accompanied by pigmentation formation. The shape of the demarcation line is formed in almost all pairs of isolates that have different types of mycelia or are not genetically identical to either monosporous or secondary mycelia (Worall 1997). In some conditions, the demarcation and barrage lines are accompanied by pigmentation. Guler (2008) explains that the presence of this pigmentation after the pairing process of two isolates is important because this pigmentation indicates an incompatibility reaction at the meeting of two different mycelia.

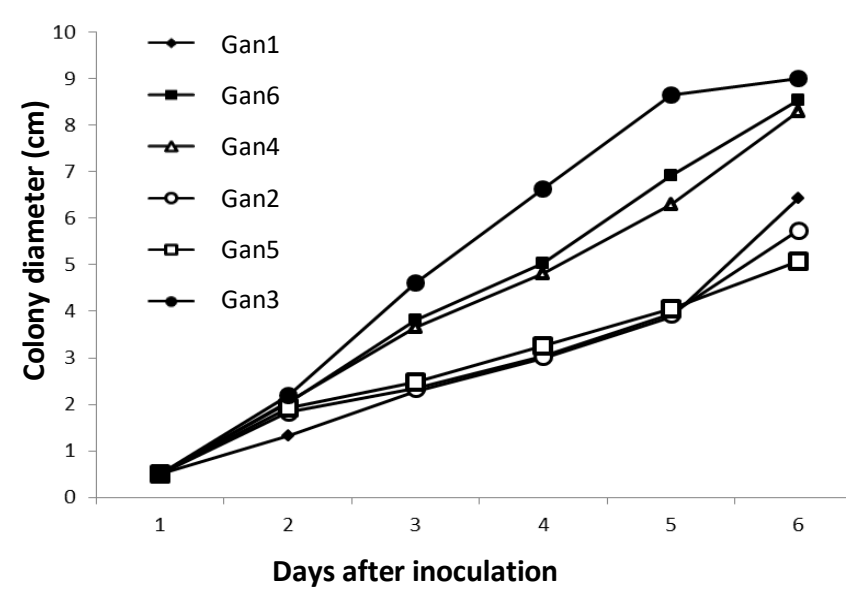

Figure 4. Growth curve trend of Ganoderma colony on PDA medium
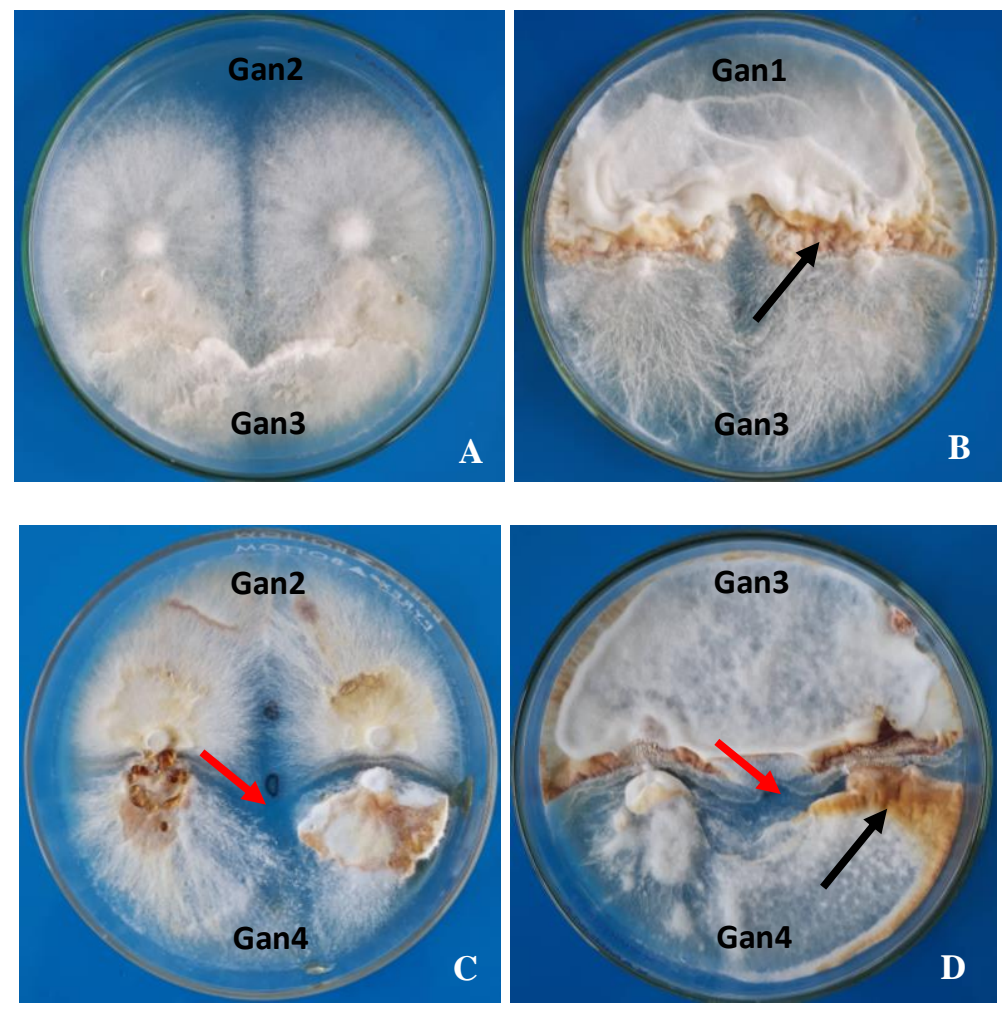

Figure 5. Somatic incompatibility form of Ganoderma isolates. A. Barrage, B. Barrage with pigmentation (black arrow), C. Inhibition zone (red arrow), D. Inhibition zone with pigmentation (black arrow) 
Based on Figure 3 and Table 5, Gan1 and Gan6 isolates showed similar on UPGMA but also have barrage formation on somatic incompatibility. Rakib et al. (2019) also found the same case and stated that the isolates may exhibit similar morphology but genotypically different. The results of this study show that oil palm plants in smallholder plantations in Deli Makmur Village, Kampar District, Indonesia are infected by different types of Ganoderma. A dendrogram from UPGMA analysis showed there are two groups of Ganoderma and the somatic incompatibility assay showed there are six different types with barrage and inhibition variation form. Molecular identification was therefore suggested to identify different species of Ganoderma among isolates tested.

\section{ACKNOWLEDGEMENTS}

The authors say many thanks to the Institute of Research and Community Service, Universitas Riau (LPPM UNRI), Pekanbaru, Indonesia for supporting this research from DIPA with contract number 746/UN.19.5.1.3/PT.01.03/2020.

\section{REFERENCES}

Central Bureau of Statistics [BPS]. 2019. Large plantation production by crop type. BPS, Jakarta. http://bps.go.id.

Cooper RM, Flood J, Rees RW. 2011. Ganoderma boninense in oil palm plantations: current thinking on epidemiology, resistance and pathology. Planter 87: 515-526.

Darmono TW. 1998. Ganoderma in oil palm Indonesia: Current status and prospective use antibodies for detection of infection. In: Herman GE, Kubice CP. (eds.). Trichoderma and Gliocladium Volume 1: Enzymes, Biological Control and Commercial Applications. Taylor \& Francis Ltd., United Kingdom.

Elliott ML, Broschat TK. 2001. Observations and pathogenicity experiments on Ganoderma zonatum in Florida. Palms 45: 62- 72.

Elfina Y, Ali M, Saputra R. 2016. Penggunaan bahan organik dan kombinasinya dalam formulasi biofungisida berbahan aktif jamur Trichoderma pseudokoningii Rifai untuk menghambat jamur Ganoderma boninense Pat. secara in vitro. Jurnal Natur Indonesia 16: 79-90. [Indonesian]

Fries N. 1987. Somatic incompatibility and field distribution of the ectomycorrhizal fungus Suillus luteus (Boletaceae). New Phytol 107 735-739.

Guler P. 2008. Somatic incompatibility in Agaricus bitorquis (Quel.) Sacc. Afr J Biotechnol 7: 276-281.

Henessy C, Daly A. 2007. Ganoderma Diseases. Northern Territory Government, Plant Pathology, Diagnostic Services, Darwin.
Hidayati N, Nurrohmah SH. 2015. Morphological characteristics of Ganoderma steyaertanum which attacks seed orchad of Acacia mangium and Acacia auriculiformis at Wonogiri, Central Java. Jurnal Pemuliaan Tanaman Hutan 9: 117-130. [Indonesian]

Idris AS, Yamaoka M, Hayakawa S, Basri MW, Noorhasimah I, Ariffin D. 2003. PCR technique for detection of Ganoderma. MPOB Information Series, Selangor, Malaysia.

Jing CJ. 2007. Pathogenicity of Ganoderma boninense and its Biological Relationships with Ganoderma spp. from Other Palm Hosts. [Thesis]. University Sains Malaysia, Pulau Penang. [Malaysian]

Latiffah Z, Ho YW. 2005. Morphological characteristics and somatic incompatibility of Ganoderma from infected oil palm from three inland estates. Malays J Microbiol 1: 46-52.

Pilotti CA, Sanderson FR, Aitken EAB, Armstrong W. 2004. Morphological variation and host range of two Ganoderma species from Papua New Guinea. Mycopathologia 158: 251-265.

Pinaria A, Assa BH. 2017. Jamur Patogen Tanaman Terbawa Tanah. Media Nusa Creative, Malang. [Indonesian]

Peterson RR. 2006. Ganoderma: a therapeutic fungal biofactory. Phytochemistry 67: 1985-2001.

Purnamasari MI, Prihatna C, Gunawan AW, Suwanto A. 2012. Isolation and molecular identification of Ganoderma spp. associated with basal stem rot disease in oil palm. Jurnal Fitopatologi Indonesia 8: 9-15. [Indonesian]

Puspitasari D, Rimbawanto A. 2010. Somatic incompatibility test to reveal disease spread of Ganoderma philippii in Acacia mangium plantation. Jurnal Pemuliaan Tanaman Hutan 4: 49-58. [Indonesian]

Rakib MRM, Bong CFJ, Khairulmazmi A, Idris AS. 2014b. Genetic and morphological diversity of Ganoderma species isolated from infected oil palms (Elaeis guineensis). Intl J Agric Biol 16: 691-699.

Rakib MRM, Clament CFS, Syazanie AED, Darwana D. 2019. Investigation on Ganoderma infection in oil palm based on the cultural characteristics and somatic compatibility: a case study in Sandakan, Sabah. ASM Sci J 13: 23-29.

Rakib MRM, Bong CFJ, Khairulmazmi A, Idris AS. 2014a. Occurrence and spatial distribution of Ganoderma species causing upper and basal stem rot in oil palm. J Food Agric Environ 12: 360-364.

Riantin W. 2009. Uji Kesesuain Berbagai Jenis Substrat dengan Ukuran yang Berbeda terhadap Pertumbuhan dan Serangan Jamur Ganoderma boninense pada Pembibitan Awal Kelapa Sawit. [Hon. Thesis]. Riau University, Pekanbaru. [Indonesian]

Saputra R, Elfina Y, Ali M. 2019. Inhibition Ability of Flour Biofungicide Formulation with Trichoderma pseudokoningii Rifai as Active Ingredients After Storage Against Ganoderma boninense Pat. Fungus in vitro. Jurnal Budidaya Pertanian 15: 106-110. [Indonesian]

Seo GS, Kirk PM. 2000. Ganodermataceae: nomenclature and classification. In: Flood J, Bridge PD, Holderness M (eds.). Ganoderma Diseases of Perennial Crops. CABI Publishing, London.

Susanto A, Ginting PA, Surianto, Prasetyo AE. 2008. Pola penyebaran Ganoderma boninense Pat. pada perkebunan kelapa sawit (Elaeis guineensis Jacq.) di lahan gambut: studi kasus di PT. Anak Tasik Labuhan Batu Sumatera Utara. Jurnal Penelitian Kelapa Sawit 16: 135-145. [Indonesian]

Susanto A, Prasetyo AE, Priwiratama H, Wening S, Surianto. 2013. Ganoderma boninense as causal agent of upper stem rot disease of oil palm. Jurnal Fitopatologi Indonesia 9: 123-126. [Indonesian]

Worall JJ. 1997. Somatic incompatibility in Basidiomycetes. Mycologia 89: 24-36. 